\title{
HUKUM NASIONAL YANG RESPONSIF TERHADAP PENGAKUAN DAN PENGGUNAAN TANAH ULAYAT
}

(Responsive National Law on Recognition and Use of Customary Land)

\author{
Markus H Simarmata \\ Pengadilan Negeri Bogor \\ Jalan Pengadilan Nomor 10 Pabaton, Bogor Tengah, Kota Bogor \\ Email: ilbesuccess@yahoo.com
}

Naskah diterima: 28 Mei 2018; revisi: 16 Agustus 2018; disetujui: 16 Agustus 2018

\begin{abstract}
Abstrak
Mekanisme pengakuan dan penggunaan tanah ulayat di Indonesia masih menyimpan banyak tantangan utamanya di era globalisasi. Keragaman hukum adat di berbagai daerah, tumpang tindih pengaturan, ketimpangan kepemilikan lahan, serta perangkat peraturan perundang-undangan yang lebih mengutamakan kepentingan perusahaan merupakan beberapa tantangan tersebut. Tulisan ini bertujuan untuk menganalisis tantangan-tantangan tersebut dan bagaimana pemerintah dapat menjawabnya dengan merumuskan hukum nasional yang responsif. Metode yang digunakan adalah yuridis normatif sementara analisis data dilakukan secara kualitatif. Pembentukan hukum nasional yang responsif dapat dilakukan dengan meningkatkan dialog yang terbuka antara investor dan masyarakat hukum adat tentang pemilikan dan/atau pemanfaatan tanah ulayat. Pemerintah juga perlu secara serius melakukan reformasi agraria, menyelaraskan berbagai undang-undang sektoral tentang agraria, dan mendorong penyelesaian sengketa di luar pengadilan apabila terjadi sengketa agraria.

Kata Kunci: hak ulayat, hukum agrarian, hukum responsif
\end{abstract}

\section{Abstract}

The customary land recognizing and using mechanism in Indonesia still has many challenges, especially in the era of globalization. The diversity of customary law in various regions, overlapping of regulation, inequality of land ownership, and the set of laws and regulations that prioritize corporate interests are some of these challenges. This paper aims to analyze these challenges and how the government can answer them by formulating responsive national law. The method used is normative juridical while the data analysis is carried out qualitatively. The establishment of a responsive national law can be done by increasing open dialogue between investors and customary law society about the ownership and / or utilization of customary land. The government also needs to seriously carry out agrarian reform, harmonize various sectoral laws on agrarian, and encourage the settlement of disputes outside the court in the event of an agrarian dispute Keywords: customary rights, agrarian law, responsive law 


\section{A. Pendahuluan}

Di Indonesia, salah satu hukum yang merupakan pencerminan bangsa adalah hukum adat, yang merupakan penjelmaan jiwa bangsa tersebut dari abad ke abad. ${ }^{1}$ Adat yang dimiliki oleh setiap daerah adalah berbeda-beda, meskipun dasar dan sifatnya satu yaitu ke-Indonesiaannya. ${ }^{2}$ Adat tersebut selalu berkembang dan senantiasa mengikuti perkembangan masyarakat dan erat hubungannya dengan tradisi masyarakat.

Permasalahan hukum di bidang pertanahan bukan hanya terjadi pada tanah ulayat namun juga terjadi pada tanah yang dimiliki masyarakat umum, tanah negara, dan tanah di kawasan hutan. Luas daratan Indonesia yang diperuntukkan bagi pertanahan untuk rakyat sangat besar namun terjadi ketimpangan dalam kepemilikan tanah di Indonesia karena pada prakteknya hanya dimiliki oleh sebagian kecil orang. Diberlakukannya Undang-Undang Nomor 5 Tahun 1960 tentang Peraturan Dasar Pokok Agraria (UUPA) seharusnya dapat memberikan keadilan bagi sebagian besar masyarakat untuk mendapatkan tanah.

Jika dikaitkan dengan gini rasio, maka penguasaan tanah di Indonesia mendekati angka 0,59 yang berarti hanya sekitar satu persen penduduk menguasai 59 persen sumber daya agraria, tanah, dan ruang. ${ }^{3}$ Menurut Suparjo Sujadi reformasi agraria pada dasarnya bukan hanya sekedar bagi-bagi tanah semata. UUPA lahir sebagai euforia politik pada masa itu untuk menciptakan masyarakat sosialisme
Indonesia. Konsep land reform di seluruh dunia itu adalah land to the farm, tanah untuk tani. Tetapi kelemahannya dibandingkan negara lain, tidak ada insentif dari Pemerintah Indonesia bagi petani yang menyentuh ekonomi pertanian dan ekonomi kerakyatan secara riil. $^{4}$

Seharusnya arah pembangunan hukum adat, hukum perdata maupun pidana ditujukan untuk menanggapi kebutuhan semua pemangku kepentingan dalam rangka meningkatkan kesejahteraan yang berkeadilan. Dengan demikian sesuai dengan pembukaan UndangUndang Dasar Negara Republik Indonesia tujuan pembangunan hukum yaitu mewujudkan masyarakat yang adil dan makmur yang juga merupakan cita hukum Indonesia.

Oleh karena itu aparat penegak hukum maupun pemerintah tidak boleh kaku menangani permasalahan tanah terutama tanah ulayat hanya berdasarkan ketentuan hukum nasional semata namun harus dipertimbangkan tujuan pembangunan hukum itu sendiri yaitu mewujudkan kebutuhan semua pemangku kepentingan untuk memperoleh keadilan dan kemakmuran. Hal ini selaras dengan amanat Pasal 3 UUPA yang mengatur agar pelaksanaan hak-hak ulayat dan hak-hak yang serupa dengan itu dari masyarakat-masyarakat hukum adat harus diatur dan dilaksanakan sedemikian rupa sesuai dengan kepentingan nasional dan negara, yang berdasarkan atas persatuan bangsa serta tidak boleh bertentangan dengan Undang-Undang dan peraturan-peraturan lain yang lebih tinggi.

Surojo Wignjodipuro, Pengantar dan Azaz-Azaz Hukum Adat (Jakarta, Gunung Agung, 1982), hlm.1.

Ibid.

Mengintip Reforma Agraria dan Persoalan Yang Tak Kunjung Rampung, (8 Oktober 2016), <http://www. hukumonline.com/berita/baca/lt57f7bea12675c/mengintip-reforma-agraria-dan-persoalan-yang-takkunjung-rampung>

4 Ibid. 
Pengaturan mengenai hak ulayat juga tercantum dalam Penjelasan Umum angka II UUPA mengenai dasar-dasar dari hukum agraria nasional yang mengamanatkan agar bumi, air, dan ruang angkasa dalam wilayah Republik Indonesia yang kemerdekaannya diperjuangkan oleh bangsa sebagai keseluruhan, menjadi hak pula dari bangsa Indonesia, jadi tidak sematamata menjadi hak dari para pemiliknya saja. Tanah-tanah di daerah-daerah dan pulau-pulau tidaklah semata-mata menjadi hak rakyat asli dari daerah atau pulau yang bersangkutan saja. Ini juga berarti Negara, sebagai organisasi kekuasaan dariseluruh rakyat (bangsa) bertindak selaku Badan Penguasa, bukan pemilik tanah.

Untuk mencapai cita-cita bangsa dan negara dalam bidang agraria ini, perlu adanya suatu rencana (planning) mengenai peruntukkan, penggunaan, dan persediaan bumi, air dan ruang angkasa untuk pelbagai kepentingan hidup rakyat dan Negara. Melalui perencanaan ini penggunaan tanah dapat dilakukan secara terpimpin dan teratur hingga dapat membawa manfaat yang sebesar-besarnya bagi Negara dan rakyat.

Untuk merealisasikan dasar-dasar hukum agraria nasioal tersebut dibutuhkan keterbukaan dari semua pemangku kepentingan dan fleksibilitas aparat penegak hukum untuk mengubah dan memperbaiki institusi hukum yang lebih responsif terhadap kebutuhan masyarakat. Menurut Phillip Nonet dan Phillip Selznick, terdapat desakan yang kuat untuk mendorong hukum modern berkembang mengikuti kebutuhan masyarakat, meskipun untuk memulainya tidak mudah dan harus selalu dievaluasi. Secara garis besar, karakter hukum yang responsif adalah sebagai berikut: dinamika perkembangan hukum lebih mengutamakan pencapaian tujuan pengaturan hubungan manusia yang harmonis dalam setiap pertimbangan hukumnya, pencapaian tujuan pengaturan hubungan manusia yang harmonis tersebut akan mengurangi tuntutan terhadap kewajiban hukum yang sangat kaku sehingga memberikan kesempatan konsepsi publik terhadap aturan hukum yang tidak kaku dan lebih mengutamakan kepentingan umum demi tercapainya ketertiban umum.

Ketika hukum menerapkan keterbukaan dan fleksibilitas tersebut maka upaya pembelaan hukum akan dipengaruhi oleh unsur-unsur politik. Kondisi ini memberikan kemampuan kepada institusi hukum untuk memperbaiki dan mengubah budaya kerjanya. Namun kondisi ini juga dapat mengurangi integritas lembaga penegak hukum. Pada akhirnya permasalahan yang paling sulit dihadapi dari Undang-Undang yang responsif terhadap perkembangan hukum yaitu terdapatnya lingkungan yang mendesak otoritas hukum secara terus menerus untuk mencapai tujuan hukum yaitu hubungan manusia yang harmonis dan terdapatnya integritas tatanan hukum yang bergantung pada desain lembaga hukum yang lebih kompeten. ${ }^{5}$

Berdasarkan uraian tersebut maka fokus penelitian yang dilakuan penulis untuk menganalisis tantangan-tantangan pengakuan dan penggunaan tanah ulayat dan bagaimana pemerintah dapat menjawabnya dengan merumuskan hukum nasional yang responsif terhadap kedudukan tanah ulayat.

Phillip Nonet dan Phillip Selznick, Law and Society In Transition: Toward Responsive Law, hlm.101. 


\section{B. Metode Penelitian}

Bentuk penelitian ini adalah penelitian yuridis normatif ${ }^{6}$ karena meneliti secara yuridis hukum nasional yang responsif terhadap pengakuan dan penggunaan tanah ulayat dengan mengunakan norma-norma yang terdapat dalam peraturan perundang-undangan secara metodologis, sistematis, dan konsisten. Data yang digunakan adalah data sekunder yang tidak langsung didapatkan dari objek penelitian tetapi dari literatur atau buku-buku.

Penelitian ini menggunakan bahan hukum primer yaitu peraturan perundang-undangan dan bahan hukum sekunder yaitu buku-buku dan karya ilmiah yang terdapat dalam internet yang merupakan pendapat para ahli hukum. Adapun bahan hukum primer yang digunakan yaitu: UU Nomor 5 Tahun 1960 tentang Peraturan Dasar Pokok-Pokok Agraria, UU Nomor 41 Tahun 1999 tentang Kehutanan sebagaimana telah diubah dengan Undang-Undang Nomor 19 Tahun 2004 Tentang Penetapan Peraturan Pemerintah Pengganti Undang-Undang Nomor 1 Tahun 2004 tentang Perubahan Atas Undang-Undang Nomor 41 Tahun 1999 tentang Kehutanan Menjadi Undang-Undang, UU Nomor Nomor 39 tahun 2014 tentang Perkebunan dan Undang-Undang Nomor 4 Tahun 2009 tentang Pertambangan Mineral dan Batubara.

Sedangkan metode analisis data yang digunakan adalah kualitatif yaitu mendalami apa yang mendasari hukum nasional yang responsif terhadap pengakuan dan penggunaan tanah ulayat sehingga dapat ditarik kendala-kendala apa saja yang terjadi dalam implementasi hukum nasional yang responsif terhadap pengakuan dan penggunaan tanah ulayat tersebut. Metode analisis data kualitatif yaitu mendalami makna dibalik realitas atau tindakan atau data yang diperoleh dan yang diteliti atau dipelajari adalah objek penelitian yang utuh. ${ }^{7}$ Adapun bentuk laporan dalam penelitian ini adalah deskriptif analitis yaitu menyatakan sasaran penelitian secara tertulis atau lisan dan perilaku nyata yang memberikan gambaran umum tentang gejala dan menganalisisnya. ${ }^{8}$

\section{Pembahasan}

\section{Konsep Hak Ulayat Menurut Para Ahli}

Untuk mendalami analisis hak ulayat atas tanah (beschikkingsrecht) maka Juga harus dianalisis hukum adat yang hidup dan berkembang di Indonesia, karena locus hakulayat berdasarkan ruang lingkup hukum terdapat dalam masyarakat hukum adat. Berdasarkan fakta dan praktik, hukum adat menganggap masyarakat sebagai suatu "paguyuban". Konsep paguyuban dalam konteks hukum adat bermakna sebagai suatu hidup bersama, oleh karena itu seorang manusia akan menjaga hubungan dengan manusia lainnya dengan menjaga semua perasaan maupun sentimennya seperti cinta, benci, simpati, antipati, empati dan sebagainya yang baik dan kurang baik.

Merujuk pada pandangan M.M. Djojodigoeno $^{9}$ dan Muhammad Koesnoe ${ }^{10}$ hukum adat memiliki sifat-sifat yang khas yaitu:

Sri Mamudhi et al, Metode Penelitian dan Pemilihan Hukum, Jakarta; Badan Penerbit Fakultas Hukum, Universitas Indonesia, 2005, hlm.3.

Ibid.

Ibid.

Otje Salman Soemadiningrat, Rekonseptualisasi Hukum Adat Kontemporer, (Bandung: Alumni, 2002), hlm.34.

10 Mohammad Koesnoe, Hukum Adat Sebagai Suatu Model Hukum, Bagian I Historis (Bandung, Mandar Maju), 1992, hlm. 10-12 
a) Hukum adat mengandung sifat yang sangat tradisional;

b) lembaga hukum adat digunakan untuk menangani setiap persoalan hukum adat yang diperlakuan secara khusus sesuai dengan fakta yang terjadi dan terkait dengan persoalan individu tertentu.

c) Hukum adat dapat berubah dan berkembang secara berkesinambungan melalui keputusan-keputusan atau penyelesaianpenyelesaian yang dikeluarkan oleh masyarakat sebagai hasil kesepakatan rasa dan pikir masyarakat melalui permusyawaratan; dan

d) Kesanggupan hukum adat untuk menyesuaikan diri dalam menyelesaikan permasalahan hukum untuk mencapai tujuan dengan tidak mempergunakan aturan-aturan detail yang pre-existen.

Hukum adat dengan karakteristik sebagaimana dikemukakan di atas kemudian dilaksanakan oleh masyarakat hukum adat. Ketika terjadi sengketa, maka penyelesaiannya pun akan dilakukan oleh masyarakat hukum adat. Menurut Ter Haar, ${ }^{11}$ Soepomo, ${ }^{12}$ dan Hazairin ${ }^{13}$ dapat persyaratan hukum adat adalah sebagai berikut: a) Terdapat masyarakat yang teratur; b) Menempati suatu tempat tertentu; c) Ada kelembagaannya; d) Memiliki kekayaan bersama; e) Susunan masyarakat berdasarkan pertalian suatu keturunan atau berdasarkan lingkungan daerah; e) Hidup secara komunal.

Untuk memenuhi seluruh kebutuhan hidupnya, melakukan kerjasama dan menjalin hubungan di antara anggota masyarakat hukum adat terbentuklah peradaban-peradaban yang dilakukan berulang-ulang. Peradaban ini menjadi suatu kebiasaan yang dapat berubah sesuai dengan perkembangan zaman seperti adat istiadat perkawinan, prosesi kematian, termasuk tata cara memperoleh dan memanfaatkan tanah. Masyarakat menyebut tata cara memperoleh dan mengolah tanah tersebut dengan "hak ulayat" (beschikkingsrecht).

Merujuk kepada pendapat 6 (enam) ahli tentang hak ulayat yakni, Mr. CCJ Maasen dan APG Hens, ${ }^{14}$ Cornelis Van Volenhoven, ${ }^{15}$ G. Kertasapoetra dan kawan-kawan, ${ }^{16}$ Elviriadi, ${ }^{17}$ Farida Pattingi, ${ }^{18}$ dan Boedi Harsono ${ }^{19}$ Penulis menyimpulkan bahwa hak ulayat merupakan suatu hak tertinggi, wewenang dan kewajiban yang dimiliki oleh masyarakat hukum adat pada suatu desa atau suku atas tanah, perairan dan isinya yang tidak dapat dipecah-pecahkan dan mempunyai dasar keagamaan, adat dan kemauan yang ada hanya di Indonesia untuk menguasai dan menjamin ketertiban pemanfaatan / pendayagunaan tanah, perairan dan isinya yang pelaksanaannya diatur oleh

\footnotetext{
Ter Haar dalam Bunser Muhammad, Azaz-Azaz Hukum Adat, Suatu Pengantar, Pradnya Paramita, Jakarta, hlm.1 Soepomo, Bab-Bab Tentang Hukum Adat, Pradnya Paramita, Jakarta, 1981

Soerjono Soekanto, Hukum Adat Indonesia, Raja Grafindo Persada, Jakarta, 1981.

Eddy Ruchiyat, "Politik Pertanahan Nasional Sampai Orde Reformasi “ (Bandung: Alumni, 1999), hlm. 32.

Ibid, hlm. 33

16 G. Kertasapoetra, R.G. Kertasapoetra, AG Kartasapoetra, A Setiady, Hukum Tanah, Jaminan Undang-Undang Pokok Agraria Bagi Keberhasilan Pendayagunaan Tanah (Jakarta: Bina Aksara, 1985), hlm. 88 .

17 Elviriadi, Sebuah Kitab Hutan Untuk Negeri Gundul Mereguk Kearifan Tetua Kampar, (Suska Perss, Pekanbaru, 2007), hlm. 82-83.

18 Farida Pattinggi, www.asdarfh.wordpres.com Hak Ulayat Masyarakat Hukum Adat.

19 Boedi Harsono, Hukum Agraria Indonesia, Sejarah Pembentukan Undang-Undang Pokok Agraria, Isi dan Pelaksanaannya, (Jakarta: Djambatan, 1999).
} 
ketua persekutuan yaitu kepala suku atau kepala desa dalam lingkungan daerahnya buat kepentingan anggota-anggotanya atau untuk kepentingan orang lain (orang asing) dengan membayar kerugian kepada desa, dalam hal mana desa itu sedikit banyak turut campur dengan pembukaan dan pengelolaan tanah, perairan, dan isinya yang dilakukan secara turun temurun dan telah berlangsung sejak lama, sehingga status tanah ulayat secara adat sangat kuat, dan turut bertangung jawab terhadap perkara-perkara yang terjadi di situ yang belum dapat diselesaikan serta menjaga kelestarian flora dan fauna dan lingkungan di daerah tersebut.

Selanjutnya C Van Vollenhoven dalam bukunya yang berjudul Een Adat - Wetboekje Voor Het Indonesie (1925) menguraikan lebih rinci tentang pengaturan, pengelolaan dan pelepasan sementara hak atas tanah adat, yaitu sebagai berikut:

a) Beschikkingsrecht atas tanah hanya dapat dimiliki oleh persekutuan hukum (gemeenschappen) dan tidak dapat dimiliki oleh perseorangan.

b) Beschikkingsrecht tidak dapat dilepaskan untuk selama-lamanya;

c) Jika hak itu dilepaskan untuk sementara, bilamana alasan selain kerugian untuk penghasilan-penghasilan yang hilang harus dibayar juga cukai (heffingen) oleh orang-orang asing, menurut hukum adat diwajibkan membayar kepada persekutuan hukum (gemeenschappen) yang memiliki tanah itu.
Berdasarkan argumentasi C Van Vollenhoven tersebut maka dapat disimpulkan bahwa hak ulayat (beschikingsrecht) atas tanah tersebut merupakan milik persekutuan hukum (gemeenschappen) masyarakat adat yang tidak dapat dilepaskan selama-lamanya serta tidak boleh dimiliki oleh perseorangan. Ciriciri yang membedakan hak ulayat dengan hak milik lainnya dijelaskan oleh C Van Vollenhoven sebagai berikut: ${ }^{20}$

a) Persekutuan hukum dan anggota-angotanya berhak dengan bebas menggunakan, mengenyam kenikmatan menggarap tanah dalam wilayah persekutuan hukum tersebut.

b) Orang-orang yang bukan anggota persekutuan hukum harus mendapat izin terlebih dahulu dari Kepala Persekutuan dengan membayar ganti kerugian.

c) Dalam menggunakan tanah, anggota persekutuan hukum tidak membayar, tetapi bagi orang luar (asing) harus membayar uang pemasukan (recognitie/contributie).

d) Persekutuan hukum bertanggungjawab atas kejahatan (pembunuhan) dalam wilayah persekutuan hukumnya apabila si pelaku tidak bisa digugat atau tidak dikenal.

e) Persekutuan tidak boleh memindahtangankan (menjual, memberi) untuk selama-lamanya kepada siapapun juga kecuali dalam hal-hal tertentu dan sangat khusus.

f) Persekutuan hukum tetap mempunyai hak campur tangan atas hak individu.

Menurut Maria S.W. Soemardjono ${ }^{21}$ kriteria untuk menentukan apakah pada suatu daerah

20 Budi Riyanto, Pengaturan Hukum Adat di Indonesia, Lembaga Pengkajian Hukum Kehutanan dan Lingkungan, Bogor, 2004, hlm.4.

21 Maria S W Sumardjono, Kebijakan Pertanahan, Antara Regulasi dan Implementasi", (Jakarta: Penerbit Buku Kompas, 2001), hlm. 57. 
masih ada atau tidak ada hak ulayat, harus diukur pada 4 (empat) indikator berikut:

a) Adanya masyarakat hukum adat yang memenuhi ciri-ciri tertentu, sebagai subyek hak ulayat;

b) Adanya tanah/ wilayah dengan batasbatas tertentu sebagai lebensraum yang merupakan obyek hak ulayat; dan

c) Adanya kewenangan masyarakat hukum adat untuk melakukan tindakan-tindakan tertentu seperti: mengatur dan menyelenggarakan penggunaan tanah (untuk pemukiman, bercocok tanam, dan lain-lain), persediaan (pembuatan pemukiman/persawahan baru dan lain-lain) dan pemeliharaan tanah.

d) Adanya hak-hak dan kewajiban masyarakat hukum adat sebagai pemegang hak pengelolaan.

Untuk menentukan masih ada atau tidak adanya hak ulayat maka dapat digunakan keempat kriteria tersebut secara utuh atau kumulatif, sehingga apabila terdapat masyarakat hukum dan terdapat tanah atau wilayahnya, namun masyarakat hukum tersebut sudah tidak memiliki kewenangan untuk mengimplementasikan keempat tindakan tersebut, maka hak ulayat dapat dikategorikan sudah tidak ada lagi.. 22 Dengan demikian hak milik atau kepemilikan atas tanah-tanah ulayat seperti "tanah bengkok" ${ }^{23}$ dan "tanah titisara ${ }^{24}$ ataupun tanah hak kaula (di Aceh) yang lembaga desanya telah dihapuskan dan dirubah menjadi kelurahan diserahkan kepada pemerintah kabupaten atau kota. Sebab masyarakat hukum adat tidak lagi memiliki kewenangan atas tanahtanah ulayat tersebut. ${ }^{25}$

\section{Permasalahan Hukum Agraria Dalam Menghadapi Globalisasi}

Kondisi demografi Indonesia dengan jumlah penduduk yang meningkat dengan pesat sebagaimana yang dipublikasikan oleh Badan Pusat Statistik (BPS) yang memproyeksikan jumlah penduduk Indonesia pada tahun 2020 yaitu sebesar 271.066 .400 orang $^{26}$. Selain itu kondisi ini juga semakin memprihatinkan dengan tingkat pendidikan dan keterampilan yang masih relatif rendah sesuai dengan publikasi BPS yang menyatakan bahwa angka penduduk Indonesia yang tidak sekolah menurut BPS tahun 2017 yaitu sebesar 2,91\%, kemudian yang tidak menamatkan Sekolah Dasar (SD) yaitu sebesar $11,43 \%$ selanjutnya yang hanya tamat SD yaitu sebesar $27,83 \%$, kemudian yang hanya menamatkan SMP sebesar $21,84 \%$ dan yang hanya menamatkan SMA sebesar $36 \%^{27}$. Semua keadaan ini mengakibatkan mayoritas penduduk Indonesia masih menggantungkan pekerjaannya pada sektor pertanian untuk mempertahankan kehidupannya dalam mencukupi kebutuhan sandang, pangan dan papannya.

Berikut disajikan tabel lapangan pekerjaan utama dari tahun 2016 hingga tahun 2017 untuk menjelaskan banyak penduduk Indonesia yang

\footnotetext{
2 Ibid, hlm.57.

23 Yaitu tanah yang merupakan hak imbalan jabatan yang diberikan kepada kepala desa, Djuhaenda Hasan, Op.Cit.

4 Ibid, yaitu tanah yang merupakan sumber kas pemeliharaan desa dan gaji pegawai desa.

Ibid.

26 Data Badan Pusat Statitik, https://www.bps.go.id/statictable/2014/02/18/1274/proyeksi-penduduk-menurutprovinsi-2010---2035.html

27 Data Badan Pusat Statistik, https://www.bps.go.id/statictable/2010/03/19/1525/indikatorpendidikan-1994-2017.html
} 
bekerja di sektor yang kurang membutuhkan tingkat pendidikan yang tinggi.

Tabel 1. Lapangan Pekerjaan Utama Tahun 2016 hingga 2017

\begin{tabular}{llcc}
\hline No & $\begin{array}{c}\text { Lapangan } \\
\text { Pekerjaan Utama }\end{array}$ & $\mathbf{2 0 1 6}$ & $\mathbf{2 0 1 7}$ \\
\hline 1. & Pertanian & 37.770 .165 & 35.923 .886 \\
\hline 2. & Industri & 15.540 .234 & 17.008 .865 \\
\hline 3. & Perdagangan & 26.689 .630 & 28.173 .571 \\
\hline 4. & Jasa & 19.459 .412 & 20.481 .956 \\
& $\begin{array}{l}\text { Kemasyarakatan, } \\
\text { Sosial dan } \\
\end{array}$ & & \\
\hline
\end{tabular}

Sumber: Badan Pusat Statistik (BPS). ${ }^{28}$

Tabel di atas menunjukkan bahwa lapangan pekerjaan utama yang paling dominan dilakukan oleh penduduk Indonesia adalah sektor pertanian dengan jumlah sebesar 35.923.886 orang.

Besarnya jumlah penduduk yang menggantungkan pekerjaannya pada sektor pertanian menyebabkan penduduk membutuhkan lahan pertanian yang besar sehingga menyebabkan pemerintah harus arif dan bijaksana untuk mengatur pendaftaran, pendistribusian, dan pemanfaatan tanah di tengah derasnya arus globalisasi saat ini.

Menurut Alm. Prof Ramli Hutabarat, Kabid Penelitian dan Pengembangan HAM, Kementerian Hukum dan HAM, masyarakat hukum adat makin banyak yang terjepit sehingga harus mengemis ke kota terlebih dengan derasnya arus globalisasi. Tanah adat sebagai bagian integral dari masyarakat adat harus dilindungi oleh negara namun perlindungan terhadap masyarakat itu harus didekati baik secara sosial, ekonomis dan yuridis. Diperlukan perangkat-perangkat hukum yang tepat untuk mengatasi masalah-masalah yang muncul dari pertarungan arus modernisasi dan masyarakat adat untuk melindungi hak masyarakat hukum adat. Diperlukan political will dari pemerintah untuk menjamin kepemilikan tanah ulayat. ${ }^{29}$

Berdasarkan pendapat tersebut maka upaya untuk memelihara, mendaftarkan, mendistribusikan, mengurus, danmemanfaatkan tanah beserta hasil yang diperoleh oleh tanah maupun kekayaan alam yang terkandung di dalam tanah harus diatur dan dikelola dengan baik sehingga sesuai dengan amanat UUD 1945 dapat memberikan kemakmuran yang sebesarbesarnya bagi rakyat. Di samping itu perlu pula diatur agar pendistribusian dan pemanfaatan tanah khususnya tanah ulayat yang ditujukan pada kemakmuran rakyat dapat bersinergi dan berinteraksi dengan perkembangan dunia internasional di era globalisasi sehingga dapat mencegah potensi terjadinya sengketa maupun konflik di sektor agraria atau pertanahan.

Untuk menjamin hak-hak masyarakat hukum adat dan hak masyarakat yang berada dalam kawasan tertentu, yang menguasai tanah dalam jangka waktu yang cukup lama maka pemerintah telah mengesahkan Peraturan Menteri Agraria dan Tata Ruang/Kepala Badan Pertanahan Nasional Nomor 10 Tahun 2016 (Permen ATR/KBPN No.10 Tahun 2016) tentang Tata Cara Penetapan Hak Komunal Atas Tanah Masyarakat Hukum Adat Dan Masyarakat yang Berada Dalam Kawasan Tertentu. Pada Pasal

${ }_{28}$ https://www.bps.go.id/statictable/2009/04/16/970/penduduk-15-tahun-ke-atas-yang-bekerja-menurutlapangan-pekerjaan-utama-1986---2017.html

29 Ramli Hutabarat Dalam Seminar Kebijakan Pertanahan Pemerintah Terhadap Hak Atas Tanah Masyarakat Adat, Badan Penelitian dan Pengembangan HAM Kementerian Hukum dan HAM RI Kerjasama Dengan Kantor Wilayah Kementerian Hukum dan HAM RI, Pekanbaru 13 Mei 2011. 
2 ayat 1 dan 2 Permen ATR/BPN No.10 Tahun 2016 diatur agar masyarakat hukum adat yang memenuhi persyaratan dapat dikukuhkan hak atas tanahnya dan kelompok masyarakat yang berada dalam suatu kawasan tertentu yang memenuhi persyaratan dapat diberikan hak atas tanah. Namun setelah dianalisa secara mendalam ternyata Permen ATR/KBPN No.10 Tahun 2016 telah mempersamakan masyarakat adat dengan masyarakat yang berada dalam Kawasan Tertentu sebagai subjek hak komunal. Masyarakat Adat dan Masyarakat yang berada dalam Kawasan Tertentu sejatinya mempunyai ciri-ciri yang sangat berbeda. Mempersamakan keduanya telah mengaburkan eksistensi hak ulayat sebagai hak pengelolaan, kepemilikan serta penguasaan tanah oleh Masyarakat Adat. Pemberlakuan Permen ATR/KBPN No.10/2016 yang mengakibatkan Kaburnya hak pengelolaan, kepemilikan serta penguasaan tanah oleh Masyarakat Adat juga berimplikasi pada tidak jelasnya keberadaan hak ulayat dalam tatanan hukum Indonesia, tidak pastinya kedudukan hukum hak penguasaan, kepemilikan, serta penguasaan tanah masyarakat adat, terjadinya penyederhaan bentuk hak ulayat masyarakat adat yang diwujudkan dalam bentuk hak komunal, timbulnya kemungkinan tumpang tindih antara Masyarakat Adat dengan masyarakat dalam kawasan tertentu pada satu objek yang sama.

Dengan demikian persoalan ini harus ditanggapi dengan serius dan konstruktif sehingga dalam era globalisasi ini masyarakat hukum adat dapat memperoleh manfaat dari proses globalisasi untuk meningkatkan kesejahteraan dan kemakmuran rakyat dan menghindari persaingan yang tidak sehat yang dapat mengakibatkan masyarakat hukum adat menjadi korban globalisasi. Oleh karena itu pemerintahharusmampumewujudkaninterelasi yang harmonis dan saling menguntungkan antara rakyat Indonesia dengan tanah serta seluruh permasalahan-permasalahan dan lembaga-lembaga kemasyarakatan yang terkait, baik dalam sendi-sendi kehidupan politik, ekonomi, sosial maupun budaya.

Menurut Sekretaris Jenderal Konsorsium Pembaharuan Agraria (KPA), Iwan Nurdin, konflik agraria telah lama terjadi dan sulit diselesaikan jika menggunakan pendekatan tata hukum biasa. Penyelesaian konflik cenderung meredakan konflik itu dengan menerapkan kepastian hukum tetapi mengabaikan rasa keadilan masyarakat. Akar masalah konflik tersebut adalah tidak diimplementasikannya Undang-Undang Pokok Agraria yang pro rakyat sejak orde baru hingga saat ini. Di samping itu disahkan pula Undang-Undang Sektoral yang tidak merujuk Undang-Undang Pokok Agraria, seperti: UU Kehutanan, UU Perkebunan, Minerba. Masih terdapat pandangan bahwa UU Sektoral tersebut tidak terkait dengan agraria padahal yang dimaksud dengan agraria adalah bumi, air, ruang angkasa dan kekayaan alam di dalamnya sebagai satu kesatuan yang utuh. ${ }^{30}$

Untuk menggambarkan hal ini dengan lebih jelas, Penulis hendak menunjukkan tumpang tindih antara UUPA dengan beberapa peraturan perundang-undangan lainnya. Tumpang tindih antara UUPA dengan UU Kehutanan dapat dicermati pada hal-hal sebagai berikut: UU No.5 Tahun 1960 Tentang Peraturan Dasar Pokok-Pokok Agraria mengakui keberadaan tiga entitas dalam hubungan antara negara dengan tanah, yakni Pasal 2 UU No.5 Tahun 1960 yang

30 Dialog: 1001 Masalah Agraria, Berita Satu, 27 Oktober 2014. 
mengatur tanah yang dikuasai negara, Pasal 3 UU No.5 Tahun 1960 yang mengatur tanah (hak) ulayat masyarakat hukum adat (MHA) dan Pasal 3 UU No.5 Tahun 1960 yang mengatur tanah hak yaitu tanah yang dipunyai dengan sesuatu hak atas tanah menurut UUPA oleh orangperorangan maupun badan hukum.

Namun dalam Pasal 5 ayat (1) UU Nomor 41 Tahun 2009 tentang Kehutanan mengakui keberadaan dua entitas dalam hubungan antara negara dengan tanah, yakni hutan negara yang merupakan hutan yang berada pada tanah yang tidak dibebani hak atas tanah dan hutan hak. Sedangkan berdasarkan ketentuan Pasal 5 ayat (2) UU No.41 tahun 2009 maka hutan adat diatur sebagai hutan negara yang berada di wilayah Masyarakat Hukum Adat. Dengan demikian, hutan adat dikategorikan sebagai hutan negara.

Pengaturan terhadap status hukum tersebut berakibat terhadap dua hal:

1) UU Kehutanan tidak mengakui keberadaan hutan adat, yang sesungguhnya merupakan bagian dari hak ulayat Masyarakat Hukum Adat. Meskipun begitu, UU Kehutanan yang tidak mengakui keberadaan hutan adat tersebut, mengakui dan mengatur persyaratan keberadaan Masyarakat Hukum Adat; jika dianalisis maka di satu sisi UU Kehutanan tidak mengakui obyeknya (hutan adat) tetapi mengakui keberadaan subyeknya (Masyarakat Hukum Adat) jika memenuhi persyaratan yang ditentukan. Apabila terdapat pengaduan dan gugatan hak ulayat Masyarakat Hukum Adat mengenai hutan adat, maka pengaturan dari kedua dasar hukum tersebut untuk menyelesaikan pengaduan dan gugatan tersebut akan berbeda.
2) Mengenai status hutan, dicantumkan bahwa hutan negara adalah "hutan yang berada pada tanah yang tidak dibebani dengan hak atas tanah". Demikian pula dalam ketentuan UUPA, tanah yang tidak dibebani dengan hak atas tanah itu adalah tanah negara. Oleh karena itu akibat hukumnya yaitu: (a) tanah-tanah di kawasan hutan negara itu sesungguhnya merupakan tanah negara. Meskipun begitu, dalam pelaksanaan administrasi, terjadi kesulitan dalam pengadministrasian tanah negara di kawasan hutan. Hingga sekarang pengadministrasian tanah negara secara umum berlaku di kawasan non hutan, padahal sesuai dengan amanat UU Kehutanan tentang hutan negara, pengadministrasian tanah negara semestinya dilakukan di seluruh wilayah RI tanpa ditentukan oleh kawasan hutan atau non hutan, sebagaimana yang diperintahkan oleh Pasal 19 UUPA. Oleh karena itu dapat disimpulkan bahwa perbedaan pengaturan tentang tanah ulayat atau tanah adat antara UUPA dan UU Kehutanan adalah terjadinya kebimbangan atau keragu-raguan bagi pelaksana Undang-Undang dan penegak hukum untuk melaksanakan ketentuan yang terkait dengan tanah adat atau tanah ulayat.

Selain persoalan tumpang tindih peraturan perundang-undangan, salah satu sumber konflik agraria juga adalah ketimpangan struktur agraria yang sangat besar. ${ }^{31}$ Hingga saat ini belum terdapat Undang-Undang yang mengatur tentang luas tanah yang dapat dikuasai dengan menggunakan Hak Guna Usaha ketentuan pada Pasal 28 ayat 2 UUPA hanya mengatur agar HGU diberikan atas tanah yang luasnya

31 Ibid. 
minimal lima hektar, dengan persyaratan bahwa apabila luasnya 25 hektar atau lebih harus menggunakan investasi modal yang layak dan teknik perusahaan yang baik, sesuai dengan perkembangan zaman. Tidak terdapat satu ketentuanpun yang mengatur tentang luas maksimal HGU dalam UUPA.

Pengaturan luas tanah yang dapat dikuasai dengan menggunakan Hak Guna Usaha bahkan hanya diatur dalam Peraturan di bawahnya yaitu Permen Agraria/KBPN Nomor 3 Tahun 1999 Tentang Pelimpahan Kewenangan Pemberian Dan Pembatalan Keputusan Pemberian Hak Atas Tanah Negara yang berbeda dengan ketentuan UUPA. Pada ketentuan Pasal 8 Permen Agraria/ KBPN Nomor 3 Tahun 1999 diatur bahwa Kepala Kantor Wilayah Badan Pertanahan Nasional Propinsi memberikan keputusan mengenai pemberian Hak Guna Usaha atas tanah yang luasnya tidak lebih dari $200 \mathrm{Ha}$ (dua ratus hektar). Permen ini memberikan hak penggunaan atas tanah yang luas hanya kepada segelintir orang dan tidak memberikan kesempatan kepada mereka yang masih belum memiliki pekerjaan untuk dapat memiliki HGU agar dapat mengelola tanah yang tersedia untuk bekerja dalam melanjutkan kehidupan mereka. Jika HGU tersebut dibatasi pada luas yang lebih kecil namun cukup ideal untuk membuka usaha di atas tanah tersebut maka secara nasional hal ini sangat membantu mengurangi angka pengangguran sedangkan apabila dibatasi untuk ukuran tanah seluas 200 hektar maka semakin meningkatkan kesenjangan penduduk yang tidak memiliki lahan untuk berusaha.

Demikian pula dengan luas maksimum tanah hak guna bangunan (HGB) juga tidak diatur oleh UUPA. Ketentuan luas maksimum tanah HGB juga hanya diatur dalam peraturan di bawah Undang-Undang yaitu Peraturan
Menteri Dalam Negeri (Permendagri) No.6 tahun 1972 tentang Pelimpahan Wewenang Pemberian Hak Atas Tanah dan Permen Agraria /KBPN No.3 Tahun 1999 Tentang Pelimpahan Kewenangan Pemberian Dan Pembatalan Keputusan Pemberian Hak Atas Tanah Negara. Pasal 4 Permendagri No.6 Tahun 1972 memerintahkan keputusan pemberian HGB untuk tanah yang luasnya tidak lebih dari 2.000 meter persegi dan jangka waktunya tidak melebihi 20 tahun diberikan oleh Gubernur. Sedangkan berdasarkan Pasal 9 Permen Agraria/KBPN Nomor 3 Tahun 1999 maka luas hak guna bangunan yang diputuskan Kepala Kantor Pertanahan Nasional Propinsi tidak lebih dari $150.000 \mathrm{~m}^{2}$ (seratus lima puluh ribu) meter persegi. Ketentuan ini tentu sangat tidak adil karena akan terjadi penguasaan tanah negara melalui HGB dengan ukuran yang luas oleh pemilik modal yang besar sedangkan masyarakat ekonomi menengah ke bawah tidak memperoleh kesempatan untuk memperoleh HGB tersebut.

Pembatasan pemilikan tanah kini menjadi sangat penting karena mendesaknya kebutuhan terhadap tanah. Penguasaan terhadap tanah pertanian diatur dalam Pasal 7 UUPA yang menyatakan bahwa pemilikan dan penguasaan tanahyangmelampauibatastidakdiperkenankan agar tidak merugikan kepentingan umum. Dalam Pasal 12 dan Pasal 13 UUPA, pemerintah menegaskan usaha pencegahan monopoli swasta. Sedangkan usaha pemerintah dalam lapangan agraria yang bersifat monopoli hanya dapat diselenggarakan dengan undang-undang. Kemudian Pasal 17 UUPA mengatur tentang perlunya peraturan mengenai batas maksimum luas tanah pertanian yang dapat dimiliki oleh satu keluarga atau badan hukum. Berikutnya untuk tanah-tanah non pertanian diatur dengan 
UU No. 56 PRP Tahun 1960 Pasal 12 tentang perlunya pembatasan maksimum luas dalam jumlah (bidang) tanah untuk perumahan. Sedangkan untuk pembangunan lainnya akan diatur dengan Peraturan Pemerintah (PP).

Dalam hal ini penting juga diperhatikan bahwa struktur permodalan di INdonesia tidak diarahkan untuk mendukung petani mempunyai perusahaan-perusahaan tersebut sehingga bisa berkolaborasi dengan perbankan dan juga berkolaborasi dengan universitas. Pemerintah seharusnya hingga ke depan ini lebih memprioritaskan perkebunanperkebunan itu dimiliki oleh koperasi-koperasi petani, manajemennya bekerjasama dengan Universitas-Universitas. Serta terdapat struktur kredit tanah dari perbankan. Swasta merupakan pemilik terbesar lahan perkebunan baik perusahaan swasta yang bersifat nasional maupun asing, terutama dari Singapura dan Malaysia. Orang yang menikmati hasil pertanian kita juga bukan petani nasional tetapi pemodalpemodal besar dari asing juga. ${ }^{32}$

Berdasarkan paparan di atas dapat disimpulkan beberapa hal yang penting dalam menghadapi era globalisasi di bidang pertanahan, yaitu:

1) Globalisasi merupakan kondisi masyarakat dunia yang semakin terbuka dan tidak terkungkung oleh sekat-sekat negara yang ditandai dengan semakin tingginya persaingan di segala bidang sehingga harus dicermati dan disikapi dengan bijaksana untuk meningkatkan pembangunan dan kesejahteraan masyarakat;

2) Pesatnya peningkatan jumlah penduduk yang disertai rendahnya tingkat pendidikan masyarakat mengakibatkan masyarakat mengandalkan tanah untuk mencari nafkah melalui usaha perkebunan dan pertanian.

3) Masih timpangnya struktur agraria yang sangat mencolok sehingga sedikit orang atau badan usaha namun dapat menguasai tanah yang sangat luas, akibatnya ditolaknya akses petani untuk dapat memanfaatkan tanah sebagai faktor produksi.

4) Masih terdapat Undang-Undang Sektoral yang belum harmonis dengan UUPA yang cenderung mengutamakan kepentingan perusahaan untuk dapat mengakses tanah terhadap berbagai usaha investasi, dan belum memenuhi kebutuhan rakyat secara berimbang untuk dapat mengakses tanah sebagai tempat melakukan aktivitas bisnis.

5) Masih terjadi struktur permodalan yang tidak diarahkan pada petani untuk mempunyai perusahaan-perusahaan perkebunan namun diarahkan pada perusahaan swasta yang besar yang bersifat nasional maupun asing.

\section{Hukum Yang Responsif Terhadap Globalisasi}

Pengembangan hukum responsif sangat tepat dalam menjawab tantangan globalisasi terhadap pemanfaatan tanah ulayat untuk kepentingan bisnis dan kepentingan umum. Kejujuran sosiologis melalui keterbukaan semua pihak yang berkompeten terhadap pembangunan nasional dan pemanfaatan tanah ulayat akan memberikan data dan fakta yang lengkap tentang apa yang dibutuhkan perusahaan swasta yang akan berinvestasi dan apa yang dibutuhkan oleh masyarakat hukum adat terhadap pemanfaatan tanah ulayat yang dimiliki oleh mereka. Melalui dialogis konstruktif

32 Ibid. 
yang transparan akan terwujud kebijaksanaan yang berkeadilan terhadap pemamnfaatan tanah ulayat. Dengan demikian hukum nasional dapat tetap fleksibel, adaptif, dan selalu mengoreksi diri terhadap perkembangan hukum adat yang sinergis dengan pembangunan ekonomi, investasi dan globalisasi. Oleh karena itu dalam perspektif hukum responsif hukum yang baik adalah hukum yang lebih dari keadilan prosedural namun hukum itu harus dilaksanakan oleh orang yang berkompeten, terkait dengan pemanfaatan tanah ulayat untuk kepentingan perkebunan, pertambangan dan investasi maka layak pula ditangani oleh lembaga hukum adat untuk menangani setiap perosalan hukum adat termasuk tanah ulayat yang sesuai dengan kepentingan masyarakat hukum adat dan juga berperan serta dalam mendukung pengembangan sektor perkebunan, pertambangan dan investasi yang meningkatkan perekonomian nasional.

Selain itu masyarakat hukum adat juga harus dapat berubah dan berkembang secara berkesinambungan melalui keputusan atau penyelesaian yang menggunakan musyawarah mufakat untuk ikut serta mendukung perekonomian nasional dalam menghadapi globalisasi. Mekanisme yang biasa dilaksanakan dalam hukum adat terhadap pemanfaatan tanah ulayat untuk perkebunan, pertambangan dan investasi lainnya yaitu dengan meminta izin terlebih dahulu dari kepala persekutuan dengan membayar ganti kerugian. Sedangkan dalam pengalihan status tanah adat menjadi hak milik perusahaan swasta maka berdasarkan hukum adat yang berlaku persekutuan hukum tidak boleh memindah tangankan (menjual, memberi) untuk selama-lamanya kepada siapapun juga kecuali dalam hal-hal tertentu dan sangat khusus.

Pengkajian terhadap hukum responsif telah melanjutkan gairah terhadap teori hukum modern. Seperti Jerome Frank mencatat tujuan utama dari realis hukum adalah untuk membuat undang-undang lebih responsif terhadap kebutuhan sosial. ${ }^{33}$ Seperti realisme hukum, kejujuran sosiologis bertujuan untuk memungkinkan lembaga-lembaga hukum untuk mengambil laporan yang lebih lengkap dan cerdas tentang fakta-fakta sosial yang harus dilaksanakan dan harus diterapkan. ${ }^{34}$ Dalam perspektif ini, hukum yang baik harus menawarkan sesuatu yang lebih dari sekadar keadilan prosedural. Itu harus kompeten dan adil; ini harus membantu menentukan kepentingan publik dan berkomitmen pada pencapaian keadilan substantif.

Demikian pula dengan hukum nasional juga harus berlaku adil baik kepada perusahaan swasta, masyarakat adat, maupun kepada pemerintah, sehingga ketimpangan struktur agraria yang sangat mencolok dapat diperbaiki sehingga semua pemangku kepentingan baik masyarakat hukum adat, perusahaan swasta, maupun pemerintah dapat memanfaatkan tanah ulayat yang berkeadilan dan mensejahterahkan semua. Pemerintah juga seharusnya segera merevisi Undang-Undang sektoral yang tidak

33 Jerome Frank, "Mr Justice Holmes and Non-Euclidian Legal Thinking”.Cornell Law Quarterly 17 (1932); hlm.568, 586 Ungkapan ini juga digunakan oleh James Willard Hurst, yang berbicara tentang pengkajian "sebuah perintah hukum yang responsif dan bertanggung jawab", yang "mampu memberikan respon positif terhadap perubahan dalam konteks sosial". Lihat James Hurst, "Problems of Legitimacy in The Contemporary Legal Order", Oklahoma Law Review 24 (1971): 224, 225, 229.

34 Roscoe Pound, Jurisprudence (st Paul, Minn: West Publishing, 1959), I, hlm.350. 
harmonis dengan Undang-Undang Pokok Agraria sehingga keadilan terhadap pendistribusian dan pemanfaatan tanah khususnya tanah ulayat dapat dirasakan baik oleh masyarakat hukum adat yang memiliki ikatan historis terhadap tanah ulayat tersebut maupun oleh pengusaha swasta dan pemerintah.

Sebaiknya pemerintah dapat merealisasikan pembuatan setifikat tanah sebesar 126 juta bidang tanah yang harus diberikan kepada masyarakat. Meskipun begitu kerja keras pemerintah pada tahun 2016 yang telah memberikan 46 juta sertifikat tanah harus diapresiasi sebagai upaya nyata pemerintah untuk mengatasi konflik agraria di seluruh Indonesia. Tahun 2018 pemerintah berencana menyelesaikan sertifikat tanah masyarakat sebanyak 7.000.000 sertifikat, sedangkan pada tahun 2019 pemerintah merencanakan akan memberikan 9.000.000 sertifikat untuk masyarakat. Disamping itu pemerintah sekarang telah responsif terhadap tuntutan masyarakat untuk dapat memperoleh sertifikat tanah dengan mudah. Presiden Joko Widodo memerintahkan agar seluruh kantor KanwilKanwil BPN lebih cepat, lebih mudah dalam pelayanan sertifikat tanah dan tidak boleh mengurus surat tanah sampai bertahun-tahun serta tidak boleh dipersulit. Masalah tersebut harus diselesaikan. ${ }^{35}$

Penyelesaian sengketa pertanahan tersebut sebaiknyatidakhanya ditujukan pada masyarakat umum namun juga kepada masyarakat hukum adat. Untuk itu pemerintah daerah sebaiknya segera mendata permintaan masyarakat hukum adat untuk mengesahkan Peraturan Daerah tentang Pengakuan Tanah Ulayat Masyarakat Hukum Adat beserta memperjelas batasbatas antara tanah/hutan ulayat dengan tanah negara. Hal ini sangat penting agar masyarakat hukum adat memperoleh kepastian hukum untuk mengolah hutan/tanah ulayat serta mengetahui sampai sejauh mana tanah ulayat yang diperbolehkan bagi masyarakat hukum adat untuk dikuasai, diolah, dan dimanfaatkan.

Begitu pula dengan regulasi dan implementasi jasa keuangan yang memberikan permodalan perlu direvisi agar kemudahan penyaluran dana tidak hanya dinikmati oleh perusahaan swasta namun juga dapat dinikmati oleh masyarakat hukum adat. Pemerintah juga seharusnya memberikan keadilan baik bagi pengusaha swasta maupun kepada Badan Usaha yang dimiliki oleh anggota masyarakat hukum adat untuk membuka dan melaksanakan usaha di bidang perkebunan, pertambangan, dan lain-lain di tanah ulayat.

Bagi hukum responsif tekanan sosial dari masyarakat hukum adat agar pemerintah segera menyelesaikan sengketa tanah ulayat merupakan sumber pengetahuan dan peluang untuk mengoreksi baik hukum adat itu sendiri maupun hukum nasional. Tujuan dari koreksi ini adalah untuk mewujudkan keharmonisan hubungan antara masyarakat hukum adat sebagai pemilik tanah ulayat dengan perusahaan swasta sebagai salah satu agen pembangunan dan pemerintah sebagai regulator dan pemilik hutan negara yang bersempadan dengan tanah ulayat. Dengan demikian tujuan dari didirikannya Negara Kesatuan Republik Indonesia yaitu memberikan kesejahteraan bagi seluruh rakyat

35 Tegas, Presiden Jokowi Berpidato Nada Tinggi Percepatan Urus Sertifikat Tanah Jangan Dipersulit, Indonesia Hebat, 20 Agustus 2017, Pidato Kepala Negara saat memberikan sambutan pada penyerahan Sertifikat Ha katas Tanah di Lapangan Park \& Ride, Jalan MH Thamrin, Jakarta Pusat, pada Minggu, 20 Agustus 2017. 
Indonesia dapat terwujud. Berbeda dengan hukum nasional yang merupakan produk politik sehingga membutuhkan waktu dan biaya yang besaruntukmengubahnya sesuaiperkembangan zaman maka hukum adat merupakan produk masyarakat hukum adat yang senantiasa menyesuaikan diri untuk menyelesaikan permasalahan hukum terkait tanah ulayat untuk mencapai tujuan mewujudkan bangsa Indonesia yang damai dan sejahtera.Oleh karena itu baik hukum adat maupun hukum nasional harus siap untuk menyusun aturan-aturan dan perangkatnya dalam menghadapi derasnya arus globalisasi yang tidak lagi terkungkung oleh sekat-sekat negara yang ditandai dengan semakin tingginya persaingan di segala bidang sehingga harus dicermati dan disikapi dengan bijaksana. Disamping itu masyarakat hukum adat, perusahaan swasta maupun pemerintah juga harus memanfaatkan tanah ulayat dengan sebaik-baiknya karena besarnya peningkatan jumlah penduduk Indonesia yang memerlukan tanah untuk tempat tinggal dan tempat berusaha.

Walaupun begitu ketiga pemangku kepentingan tersebut harus selalu mencari nilai-nilai implisit dalam aturan dan kebijakan hukum adat dan nasional yang masih relevan dengan perubahan zaman. Pada dasarnya tujuan dari pencarian nilai-nilai implisit ini yaitu meningkatkan keharmonisan hubungan dari ketiga pemangku kepentingan tersebut serta menghindari kesewenang-wenangan aparat pemerintah dari batas otoritas yang didelegasikan. Berdasarkan analisis tersebut maka hukum nasional dan hukum adat yang mengutamakan tujuan yaitu mewujudkan keharmonisan hubungan antara masyarakat hukum adat, pengusaha swasta, dan pemerintah berorientasi pada hasil yaitu kesejahteraan bagi seluruh masyarakat. Dengan demikian hukum responsif sangat berbeda dengan citra hukum klasik yang tidak memperhatikan pada hasil. Dalam implementasinya sangat dibutuhkan kolaborasi antara otoritas hukum dan kemauan politik. Gagasan tentang proses yang "tetap" ini kontras dengan interpretasi "fleksibel" yang lebih melihat aturan yang terikat pada masalah dan konteks tertentu, dan berusaha untuk mengidentifikasi nilai-nilai yang dipertaruhkan dalam perlindungan prosedural. ${ }^{36}$ Ketika nilainilai ini diartikulasikan, mereka menawarkan kriteria otoritatif untuk mengkritik aturan yang ada, menghasilkan aturan baru, dan memandu perpanjangan proses hukum ke pengaturan kelembagaan baru. ${ }^{37}$

\section{Penutup}

Mekanisme pengakuan dan penggunaan tanah ulayat di Indonesia masih menyimpan banyak tantangan utamanya di era globalisasi. Pertama, Kebiasaan-kebiasaan dari hukum adat yang satu dengan hukum adat yang lain yang berbeda-beda dapat menyebabkan investor

36 Terhadap interpretasi "tetap" dan "fleksibel" dari proses hukum lihat Sanford H Kadish, "Methodology and Criteria in Due Process Adjudication- A Survey and Criticism". Yale Law Journal 66 (Tahun 1957); hlm. 319. Terhadap upaya menguraikan proses yang fleksibel lihat Martin P Golding, "Preliminaries to the Study of Procedural Justice”, Dalam Graham Hughe, ed.,Law, Reason, and Justice (New York:New York Universities Press, 1969), hlm.71, Kenneth I Winston, "Self-Incrimination in Context: Establishing Procedural Protections in Juvenile and College Disciplinary Proceedings, “Southern California Law Review 48 (1975): 813.

37 Contoh dari alasan ini adalah perpanjangan dari proses hukum kepada "pemerintah perdata”.Lihat Philip Selznick yang berkolaborasi dengan Philippe Nonet dan Howard Vollmer, Law, Society, and Industrial Justice (New York: Russel Sage Foundation, 1969), hlm.164-178, 250 ff. 
yang berasal dari daerah yang lain kesulitan untuk menerima dan menyesuaikan dengan kebiasaan dari hukum adat yang berlaku di suatu daerah pada saat ingin membeli atau mengontrak atau memanfaatkan tanah ulayat. Kedua, masih terjadinya ketimpangan struktur agraria yang sangat mencolok sehingga sedikit orang atau badan usaha namun dapat menguasai tanah yang sangat luas, akibatnya ditolaknya akses petani untuk dapat memanfaatkan tanah sebagai faktor produksi dan masih terdapat Undang-Undang Sektoral yang belum harmonis dengan UUPA yang cenderung mengutamakan kepentingan perusahaan untuk dapat mengakses tanah terhadap berbagai usaha investasi, dan belum memenuhi kebutuhan rakyat secara berimbang untuk dapat mengakses tanah sebagai tempat melakukan aktivitas bisnis.

Untuk menjawab persoalan ini, Pemerintah perlu mendorong terwujudnya hukum nasional yang responsif dalam pengakuan dan pengelolaan tanah ulayat. Pemerintah dapat mendorong dialog yang terbuka dengan mengutamakan musyawarah untuk mencapai mufakat antara pemerintah, investor, dan masyarakat hukum adat agar diperoleh kesepakatan yang harus dipenuhi antara investor dan masyarakat hukum adat tentang pemilikan dan/atau pemanfaatan tanah ulayat. Selain itu, Pemerintah harus melanjutkan reformasi agraria dengan membuat program pemerintah tentang pengadaan tanah untuk dunia usaha melalui revitalisasi program transmigrasi yang berkeadilan dan untuk pemukiman melalui revitaliasi program Rumah Sangat Sederhana yang manusiawi sehingga dapat mengurangi ketimpangan antara sebagian kecil orang yang memiliki tanah yang luas dengan sebagian besar orang yang tidak memiliki atau memiliki sedikit tanah. Disamping itu pemerintah juga harus berkomitmen untuk menyelaraskan Undang-Undang Sektoral tentang agraria dengan Undang-Undang Pokok agraria sehingga memberikan kesempatan bagi rakyat untuk memanfaatkan tanah dan sumber daya alam yang terkandung di dalamnya.

Tergadap sengketa tanah ulayat semestinya dikedepankan mekanisme musyawarah untuk mufakat. Dis amping itu pemerintah seharusnya memilikikonsep dan alternatif penyelesaian yang dapat diajukan kepada pihak yang bersengketa. Pada dasarnya upaya yang dilakukan oleh pemerintah itu untuk mewujudkan win-win solution atau penyelesaian masalah yang menguntungkan atau bermanfaat bagi semua pihak atau pemerintah dapat menerapkan semua upaya yang terdapat dalam metode Alternatif Dispute Resolution sehingga upaya itu bukanlah ditujukan untuk mencari pemenang dari sengketa tersebut tetapi untuk mencapai kesepakatan dari pihak yang bersengketa agar tercapai penyelesaian win-win solution.

\section{Daftar Pustaka}

\section{Buku}

Afandi, Ali, Kedudukan Hukum Asing Dalam Pembinaan Tata Hukum Di Indonesia (Jakarta: Bina Aksara, 1985).

Elviriadi, Sebuah Kitab Hutan Untuk Negeri Gundul Mereguk Kearifan Tetua Kampar, (Suska Perss, Pekanbaru, 2007).

Gamal, Merza, Model Dinamika Sosial Ekonomi Islam: Pembangunan Kesejahteraan Berkesinambungan dan Berkeadilan (Pekanbaru: Badan Penerbit Universitas Riau (UNRI Press), 2006).

Haar, Ter dalam Bunser Muhammad, Azaz-Azaz Hukum Adat, Suatu Pengantar (Jakarta: Pradnya Paramita).

Harsono, Boedi, Hukum Agraria Indonesia, Sejarah Pembentukan Undang-Undang Pokok Agraria, Isi dan Pelaksanaannya, (Jakarta: Djambatan, 1999). 
Kertasapoetra, G. R.G, et.al. Hukum Tanah, Jaminan Undang-Undang Pokok Agraria Bagi Keberhasilan Pendayagunaan Tanah (Jakarta: Bina Aksara, 1985).

Koesnoe, Mohammad, Hukum Adat Sebagai Suatu Model Hukum, Bagian I Historis (Bandung: Mandar Maju), 1992.

Mamudji, Sri et al. Metode Penelitian dan Pemilihan Hukum (Jakarta: Badan Penerbit Fakultas Hukum, Universitas Indonesia, 2005).

Muhammad, Bushar, Pokok-Pokok Hukum Adat (Jakarta: Pradnya Paramita, 1983).

Nonet, Phillip and Selznick,Phillip, Law and Society In Transition: Toward Responsive Law (Newyork, USA: Routledge, Taylor and Francis Group, 2017)

P Golding, Martin, Preliminaries to the Study of Procedural Justice, Dalam Graham Hughe, ed.,Law, Reason, and Justice (New York: New York Universities Press, 1969).

Pound, Roscoe, Jurisprudence (st Paul, Minnesotta: West Publishing, 1959).

Riyanto, Budi, Pengaturan Hukum Adat di Indonesia (Bogor, Lembaga Pengkajian Hukum Kehutanan dan Lingkungan, 2004).

Ruchiyat, Eddy, Politik Pertanahan Nasional Sampai Orde Reformasi (Bandung: Alumni, 1999).

Salman Soemadiningrat, Otje, Rekonseptualisasi Hukum Adat Kontemporer (Bandung: Alumni, 2002).

Selznick,Philip, Nonet,Philippe and Vollmer,Howard, Law, Society, and Industrial Justice (New York: Russel Sage Foundation, 1969).

Soekanto, Soerjono, Hukum Adat Indonesia (Jakarta: Raja Grafindo Persada, 1981)

Soepomo, Bab-Bab Tentang Hukum Adat (Jakarta: Pradnya Paramita, 1981)

S W Sumardjono, Maria, Kebijakan Pertanahan, Antara Regulasi dan Implementasi, (Jakarta: Penerbit Buku Kompas, 2001).

Ter Haar, B., Asas-Asas dan Susunan Hukum Adat (Jakarta: Pradnya Paramita, 1980).

Wignjodipuro,Surojo, Pengantar dan Azaz-Azaz Hukum Adat (Jakarta: Gunung Agung, 1982).

Wiradi, Gunawan dalam Noer Fauzi, Penghancuran Populisme dan Pembangunan Kapitalisme, Dinamika Politik Agraria Pasca Kolonial dalam Dianto Bachriadi, Erfan Faryadi, et al (Ed), Perubahan Politik "Sengketa dan Agenda Pembaruan Agraria di Indonesia, Reformasi Agraria, (Jakarta: Lembaga Penerbit Fakultas Ekonomi, Universitas Indonesia, 1997).

\section{Makalah/Artikel/Prosiding/Hasil Penelitian}

Artikel dalam Jurnal: Frank, Jerome, "Mr Justice Holmes and Non-Euclidian Legal Thinking", Cornell Law Quarterly 17 (1932);

Artikel dalam Jurnal: H. Kadish, Sanford, "Methodology and Criteria in Due Process Adjudication- A Survey and Criticism". Yale Law Journal 66 (1957).

Artikel dalam Jurnal: Hurst, James, "Problems of Legitimacy in The Contemporary Legal Order", Oklahoma Law Review 24 (1971):

Artikel dalam jurnal: I Winston, Kenneth, "SelfIncrimination in Context: Establishing Procedural Protections in Juvenile and College Disciplinary Proceedings", Southern California Law Review 48 (1975).

Tulisan dalam materi kuliah: Hasan, Djuhaendah, "Hukum Agraria Lanjut" (kuliah disampaikan pada Program Pascasarjana Universitas Padjajaran di Bandung tanggal 11 November 2002).

Tulisan dalam seminar: Ramli Hutabarat "Kebijakan Pertanahan Peemrintah Terhadap Hak Atas Tanah Masyarakat Adat" (Makalah disampaikan pada Seminar yang diselenggarakan oleh Badan Penelitian dan Pengembangan HAM Kementerian Hukum dan HAM RI bekerjasama dengan Kantor Wilayah Kementerian Hukum dan HAM RI Pekanbaru 13 Mei 2011).

Pidato Kepala Negara: "Tegas, Presiden Jokowi Berpidato Nada Tinggi Percepatan Urus Sertifikat Tanah Jangan Dipersulit, Indonesia Hebat, 20 Agustus 2017", Pidato Kepala Negara disampaikan pada sambutan penyerahan Sertifikat Hak atas Tanah di Lapangan Park \& Ride, Jalan MH Thamrin, Jakarta Pusat, pada Minggu, 20 Agustus 2017.

\section{Internet}

BPS, "Data Badan Pusat Statitik", https://www.bps. go.id/statictable/2014/02/18/1274/proyeksipenduduk-menurut-provinsi-2010---2035.html

BPS, "Data Badan Pusat Statistik", https://www. bps.go.id/statictable/2010/03/19/1525/ indikator-pendidikan-1994-2017.html

Hukum Online, "Mengintip Reforma Agraria dan Persoalan Yang Tak Kunjung Rampung", http://www.hukumonline.com/berita/ baca/lt57f7bea12675c/mengintip-reformaagraria-dan-persoalan-yang-tak-kunjungrampung diakses (8 Oktober 2016) 
Farida Pattinggi, "Hak Ulayat Masyarakat Hukum Adat", www.asdarfh.wordpres.com.

\section{Peraturan}

Undang-Undang Nomor 5 Tahun 1960 tentang Peraturan Dasar Pokok Agraria

Undang-Undang Nomor 41 Tahun 1999 tentang Kehutanan sebagaimana telah diubah dengan Undang-Undang Nomor 19 Tahun 2004 Tentang
Penetapan Peraturan Pemerintah Pengganti Undang-Undang Nomor 1 Tahun 2004 tentang Perubahan Atas Undang-Undang Nomor 41 Tahun 1999 tentang Kehutanan Menjadi Undang-Undang

Undang-Undang Nomor Nomor 39 tahun 2014 tentang Perkebunan

Undang-Undang Nomor 4 Tahun 2009 tentang Pertambangan Mineral dan Batubara 